\title{
Methane Production and Consumption in Loess Soil at Different Slope Position
}

\author{
Małgorzata Brzezińska, Magdalena Nosalewicz, Marek Pasztelan, and Teresa Włodarczyk
}

Institute of Agrophysics, Polish Academy of Sciences, Ulica Doświadczalna 4, 20290 Lublin, Poland

Correspondence should be addressed to Małgorzata Brzezińska, m.brzezinska@ipan.lublin.pl

Received 31 October 2011; Accepted 2 January 2012

Academic Editor: Hubert Hasenauer

Copyright ( $) 2012$ Małgorzata Brzezińska et al. This is an open access article distributed under the Creative Commons Attribution License, which permits unrestricted use, distribution, and reproduction in any medium, provided the original work is properly cited.

\begin{abstract}
Methane $\left(\mathrm{CH}_{4}\right)$ production and consumption and soil respiration in loess soils collected from summit (Top), back slope (Middle), and slope bottom (Bottom) positions were assessed in laboratory incubations. The $\mathrm{CH}_{4}$ production potential was determined under conditions which can occur in the field (relatively short-term flooding periods with initially ambient $\mathrm{O}_{2}$ concentrations), and the $\mathrm{CH}_{4}$ oxidation potential was estimated in wet soils enriched with $\mathrm{CH}_{4}$. None of the soils tested in this study emitted a significant amount of $\mathrm{CH}_{4}$. In fact, the Middle and Bottom soils, especially at the depth of 20-40 cm, were a consistent sink of methane. Soils collected at different slope positions significantly differed in their methanogenic, methanotrophic, and respiration activities. In comparison with the Top position (as reference soil), methane production and both $\mathrm{CO}_{2}$ production and $\mathrm{O}_{2}$ consumption under flooding were significantly stimulated in the soil from the Middle slope position $(P<0.001)$, while they were reduced in the Bottom soil (not significantly, by 6 to $57 \%)$. All upper soils $(0-20 \mathrm{~cm})$ completely oxidized the added methane $(5 \mathrm{kPa})$ during $9-11$ days of incubation. Soils collected from the $20-40 \mathrm{~cm}$ at the Middle and Bottom slope positions, however, consumed significantly more $\mathrm{CH}_{4}$ than the Top soil $(P<0.001)$.
\end{abstract}

\section{Introduction}

Methane $\left(\mathrm{CH}_{4}\right)$ is the most abundant hydrocarbon in the atmosphere, and it is an important greenhouse gas, which so far has contributed to an estimated $18-20 \%[1,2]$ of postindustrial global warming. Methane has environmental impacts beyond those of a direct greenhouse gas, through atmospheric chemistry that enhances the abundance of tropospheric ozone $\left(\mathrm{O}_{3}\right)$ and decreases that of hydroxyl radicals $(\mathrm{OH})$ and hence the atmospheric lifetime of many other pollutants [3]. The atmospheric $\mathrm{CH}_{4}$ concentration has risen from the background level from 700 to $1782 \mathrm{ppb}$ in 2006, and the growth rate in $\mathrm{CH}_{4}$ concentration was changing considerably; the very large and interannual variations in $\mathrm{CH}_{4}$ concentration remain unexplained and present an important challenge to the research community $[4,5]$. Estimated surface $\mathrm{CH}_{4}$ emissions reach $643 \mathrm{Tg}$ year $^{-1}$ [3]. Oxidation of atmospheric methane by well-drained soils accounts for about $10 \%$ [6] or $6 \%$ [4] of the global methane sink, that is about $30 \mathrm{Tg} \mathrm{CH} 4$ per year. Other $\mathrm{CH}_{4}$ sinks are the stratosphere $\left(40 \mathrm{Tg}\right.$ year $\left.^{-1}\right)$ and tropospheric $\mathrm{OH}(445 \mathrm{Tg}$ year $\left.^{-1}\right)[4]$.

Most methane on Earth is produced by Archaea through methanogenesis, the final step in fermentation of organic matter, which takes place in rice fields, the guts of animals, soils, wetlands, and landfills, as well as in freshwater and marine sediments. As a simple assumption, about $10-20 \%$ of reactive organic material buried in soils and sediments is converted to methane [1]. The potential impact of methane on future global warming and an important role of soils in sorption of this gas have led to many terrestrial studies of methods and techniques to quantify $\mathrm{CH}_{4}$ flux at the soilatmosphere interface [7]. Numerous experimental data on emission of greenhouse gases are used in modelling of the local and global gas emissions, while some models were developed to determine abatement strategies to meet restrictions on emission and/or deposition levels at the least cost [8].

Soil saturation with water has dramatic consequences for gas diffusion processes in soil (as gases diffuse 10,000 
TABLE 1: Basic characteristics of loess soils at three slope positions.

\begin{tabular}{|c|c|c|c|c|c|c|c|}
\hline Slope position & Soil depth $(\mathrm{cm})$ & $\mathrm{C}_{\text {org }}(\%)$ & $\mathrm{C}_{\text {inorg }}(\%)$ & $\mathrm{pH}\left(\mathrm{H}_{2} \mathrm{O}\right)$ & Sand & $\begin{array}{l}\text { Silt } \\
(\%)\end{array}$ & Clay \\
\hline \multirow{2}{*}{ Top } & $0-20$ & 0.97 & 0.690 & 8.11 & 33.6 & 62.1 & 4.3 \\
\hline & $0-40$ & 0.57 & 0.002 & 8.14 & 16.2 & 77.4 & 6.3 \\
\hline \multirow{2}{*}{ Middle } & $0-20$ & 2.14 & 0.006 & 7.60 & 27.1 & 68.7 & 4.2 \\
\hline & $20-40$ & 1.42 & 0.275 & 7.91 & 27.5 & 68.3 & 4.2 \\
\hline \multirow{2}{*}{ Bottom } & $0-20$ & 0.92 & 0.657 & 7.88 & 30.9 & 64.9 & 4.2 \\
\hline & $20-40$ & 0.39 & 0.393 & 7.56 & 34.1 & 61.6 & 4.3 \\
\hline
\end{tabular}

faster in air than in water). Consequently, one of the main effects of flooding is a lower pool of available $\mathrm{O}_{2}[9,10]$ and a several-fold change in the activity of the oxidoreductases-intracellular enzymes involved in the oxidative metabolism of soil microorganisms [11]. Conventional knowledge states that water-saturated systems like wetlands (swamps, marshes) and paddy soils (rice fields) are net contributors of $\mathrm{CH}_{4}$ to the atmosphere, whereas upland soils (with the exception of landfills) are generally sinks for $\mathrm{CH}_{4}$ [12]. However, significant methane emission from field soils may also occur after normal precipitation if the soils remain saturated for a long enough period, since water occupation of soil voids may cause oxygen deficiency and development of reducing conditions. Even in unsaturated conditions, there may be anaerobic microsites capable of evolving methane. Little is known, however, about methane emission when usually well-drained soils become flooded for a short period [13]. In fact, soils can act as a source and a sink for $\mathrm{CH}_{4}$, depending on their air-water conditions $[7,14]$.

Soil properties are a product of soil-forming factors including landscape variability, agroecosystem management, and climatic factors. Numerous studies were performed to measure the effect of landscape position and land management on physical, chemical and biological soil properties [15-21]. Soils developed from loess are fertile and show high erodibility [22]. Soil erosion results in heavy differentiation of a soil cover with natural pedons being reduced or overbuilt. Both eroded and colluvial soils differ from uneroded soils not only in morphological features but also in particle-size and pore distributions, organic matter content and plant nutrients, water retention, and bulk density [23]. Loess soils are among the most susceptible to the drop in redox potential under anaerobic conditions, which is followed by a rapid reduction of the oxidized inorganic soil components [24]. In consequence, periodical soil hypoxia changes soil respiration, which plays a fundamental role in the metabolism of the soil biota and promotes development of methanogenic microorganisms.

The objective of this study was to compare the $\mathrm{CH}_{4}$ production and $\mathrm{CH}_{4}$ consumption in slightly eroded loess soils taken at the summit, back slope, and bottom of a hill. The experiment was performed in laboratory under controlled temperature and air-water conditions. Initially, ambient $\mathrm{O}_{2}$ concentrations were present in both flooded and wet soil incubations. Our intention was to determine the soil potential for methane production under conditions which occur in field (relatively short-term flooding periods for methanogenic activity) and for methane oxidation (soil enriched with $\mathrm{CH}_{4}$ ).

\section{Materials and Methods}

2.1. Site and Soil Description. A loessial agricultural basin of the Ciemięga River (near Lublin, south-east part of Poland) is a region of the water erosion risk, including sediment transport and nutrient runoff, and is under intensive agricultural use $[24,25]$. Soil samples were collected near Baszki village from two depths $(0-20 \mathrm{~cm}$ and $20-40 \mathrm{~cm})$ and three slope positions: at the summit (Top), back slope (Middle), and slope bottom (Bottom).

The slope is about $15 \mathrm{~m}$ high and $60 \mathrm{~m}$ long and is covered by natural grass vegetation; it is at the distance of about $150 \mathrm{~m}$ from the river. The annual precipitation in this region is $570 \mathrm{~mm}$, and the average annual temperature is $+7.5^{\circ} \mathrm{C}$ [25]. The basic characteristic of the tested brown loess soil (Eutric Cambisol) is shown in Table 1.

2.2. Incubation Experiment. For methanogenic activity measurements, $20 \mathrm{~g}$ portions of air-dry soils were placed into $60 \mathrm{~cm}^{3}$ glass vessels and flooded with $15 \mathrm{~cm}^{3}$ of distilled water. All the vessels were tightly closed with rubber stoppers and aluminium caps, and the flooded soils were incubated at $25^{\circ} \mathrm{C}$ for 28 days.

For methanotrophic activity measurements, $10 \mathrm{~g}$ portions of air-dried soils were placed into $60 \mathrm{~cm}^{3}$ glass vessels and $5 \mathrm{~cm}^{3}$ of distilled water was added. All the vessels were tightly closed with rubber stoppers and aluminium caps, and wet soils were enriched with $5 \%(\mathrm{v} / \mathrm{v}) \mathrm{CH}_{4}(5 \mathrm{kPa})$. The soil samples were incubated at $20^{\circ} \mathrm{C}$ for 21 days.

Initially, ambient $\mathrm{O}_{2}$ concentrations were present in both incubations $(20.5 \% \mathrm{v} / \mathrm{v})$. Our intention was to determine the potential of soils for methane production under field conditions, with relatively short-term flooding periods, and for methane oxidation after soil enrichment with $\mathrm{CH}_{4}$.

2.3. Methods. The concentrations of gases in the headspace were measured with gas chromatographs Shimadzu GC14B and GC-14A (Japan) equipped with a flame ionization detector (FID) and a thermal conductivity detector (TCD), respectively. Methane was detected by the FID detector at $150^{\circ} \mathrm{C}$. The gas components were separated on a column packed with a Porapak Q maintained at $80^{\circ} \mathrm{C}$, and the temperature of the injector was $150^{\circ} \mathrm{C}$. Carbon dioxide and $\mathrm{O}_{2}$ were detected by TCD with the use of two $2 \mathrm{~m}$ columns 


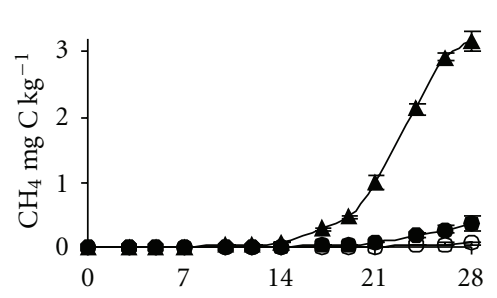

(a)

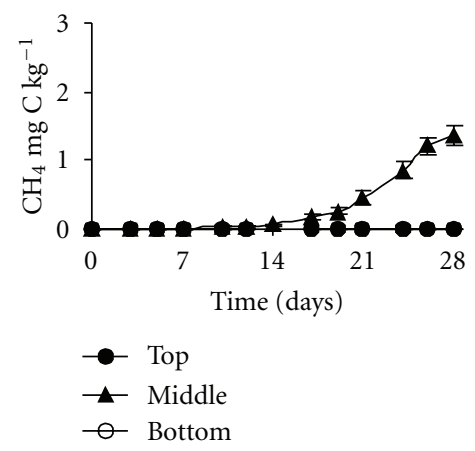

(d)

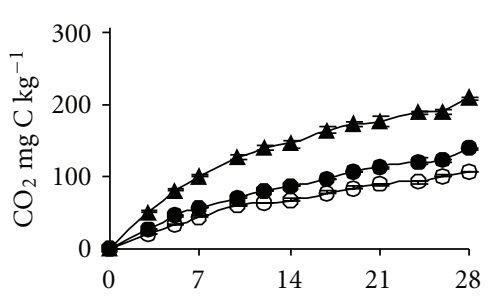

(b)

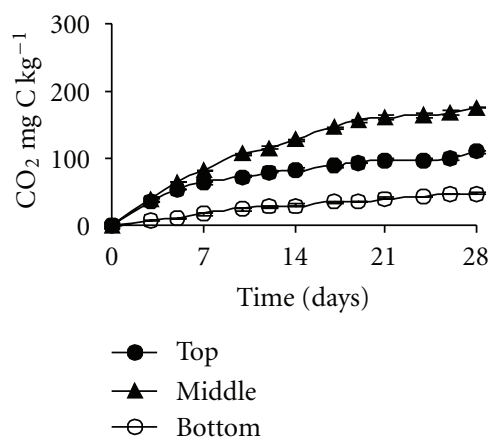

(e)

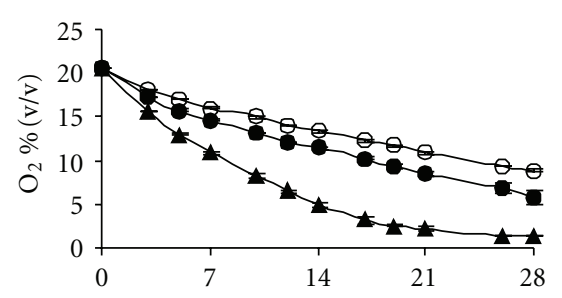

(c)

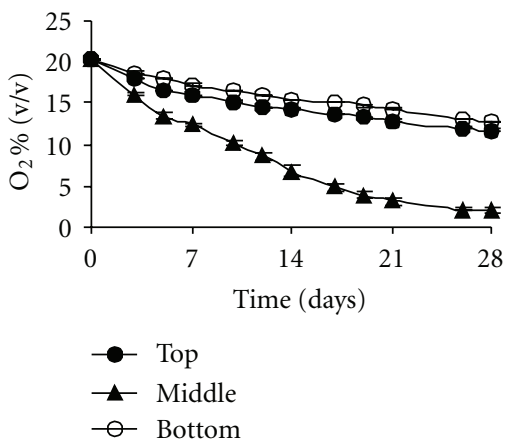

(f)

Figure 1: Changes of $\mathrm{CH}_{4}, \mathrm{CO}_{2}$ and $\mathrm{O}_{2}$ over time in loess soils collected from three slope positions and incubated under flooding (methanogenic potential). Top: summit, Middle: back slope, Bottom: bottom of the slope. Upper graphs (a-c) upper soil depth of 0-20 cm; lower graphs (d-f) lower soil depth of 20-40 cm. (a) and (d) cumulative $\mathrm{CH}_{4}$ production; (b) and (e) cumulative $\mathrm{CO}_{2}$ production; (c) and (f) changes in $\mathrm{O}_{2}$ in the headspace. Points represent triplicate-means with standard error.

(3.2 diameter), one packed with Porapak $\mathrm{Q}\left(\right.$ for $\left.\mathrm{CO}_{2}\right)$ and the other packed with Molecular Sieve $5 \mathrm{~A}\left(\right.$ for $\left.\mathrm{O}_{2}\right)$ with $\mathrm{He}$ as a carrier gas flowing at a rate of $40 \mathrm{~cm}^{3} \mathrm{~min}^{-1}$. The temperatures of the column and detector were $40^{\circ} \mathrm{C}$ and $60^{\circ} \mathrm{C}$, respectively. The detector responses were calibrated using certified gas standards (Air Products) containing 20.9\% $\mathrm{O}_{2}$ in $\mathrm{N}_{2}$ and $4 \% \mathrm{CH}_{4}$ or $1 \% \mathrm{CO}_{2}$ in $\mathrm{He}[26,27]$.

Soil properties were determined by standard methods. The organic $\left(\mathrm{C}_{\text {org }}\right)$ and inorganic $\left(\mathrm{C}_{\text {inorg }}\right)$ carbon was determined using a TOC-VCPH analyzer (Shimadzu, Japan). The particle size distribution was measured with the laser diffraction method [28]. All measurements were done in triplicate, and the results were expressed on an oven-dry weight basis $\left(105^{\circ} \mathrm{C}, 24 \mathrm{~h}\right)$.

2.4. Calculations. The concentrations of gases were corrected for solubility in water by using published values of the Bunsen absorption coefficient [29]. The rates of methane production and consumption were calculated by linear regression of increases and decreases, respectively, in $\mathrm{CH}_{4}$ concentrations against incubation time, using at least three consecutive measurements with a regression coefficient $\left(r^{2}\right)$ of $>0.9$, and expressed in $\mathrm{mg} \mathrm{CH}$ - $\mathrm{C}$ per $\mathrm{kg}$ of oven-dry soil per day $[30,31]$. The total cumulative $\mathrm{CH}_{4}$ production and $\mathrm{CH}_{4}$ consumption were determined in each sample by the difference in the headspace $\mathrm{CH}_{4}$ concentration at the beginning and end of the assay period [32]. The rates of $\mathrm{CH}_{4}$ production and consumption and the total amount of $\mathrm{CH}_{4}$ produced and consumed were used as a measure of the methanogenic and methanotrophic activity (potential), respectively. Similarly, the total amounts of $\mathrm{CO}_{2}$ produced and $\mathrm{O}_{2}$ consumed were calculated to describe the respiration activity (and expressed as $\mathrm{mg} \mathrm{CO}_{2}-\mathrm{C} \mathrm{kg}^{-1}$ and $\mathrm{O}_{2} \%(\mathrm{v} / \mathrm{v})$, resp.). Final amounts of $\mathrm{CH}_{4}, \mathrm{CO}_{2}$, and $\mathrm{O}_{2}$ were assessed by Student's " $t$ " test to determine the significance of the differences in gas production or consumption between soils. Correlations between total gases produced or consumed over time, and organic carbon in soils collected from different slope positions were tested with regression analysis.

\section{Results}

3.1. Methanogenic Activity of Soils from Different Slope Positions. Position of soil in the slope strongly affected the capacity of $\mathrm{CH}_{4}$ production. Methane was produced in flooded soils after a 17-day lag (Figure 1). The highest methanogenic activity was observed in the Middle soil. During 28-day incubation, the upper $0-20 \mathrm{~cm}$ soil evolved $3.17 \mathrm{mg} \mathrm{CH}_{4}$ $\mathrm{C} \mathrm{kg}^{-1}$ soil at a rate of $0.304 \mathrm{mg} \mathrm{CH}_{4}-\mathrm{C} \mathrm{kg}^{-1} \mathrm{~d}^{-1}$ (Figure 1(a), Table 2). Soil sampled at the Top position produced only $0.359 \mathrm{mg} \mathrm{CH} \mathrm{CH}_{4}-\mathrm{C} \mathrm{kg}^{-1}$, while the Bottom soil evolved even less than $0.06 \mathrm{mg} \mathrm{CH}_{4}-\mathrm{C} \mathrm{kg}^{-1}$.

Deeper soil layers $(20-40 \mathrm{~cm})$ showed significantly lower methanogenic activity $(P<0.001)$ with the highest production in the soil from the Middle position $1.35 \mathrm{mg} \mathrm{CH}_{4}-\mathrm{C} \mathrm{kg}^{-1}$ and much lower in the other soils: less than $0.002 \mathrm{mg} \mathrm{CH}_{4}-$ $\mathrm{C} \mathrm{kg}^{-1}$ (Figure 1(d)).

The tested soils showed relatively large differences in their respiration under flooding. Both $\mathrm{CO}_{2}$ evolution and $\mathrm{O}_{2}$ consumption were more intensive in the upper rather than deeper soil layers (Figures 1(b) and 1(c)). The Middle soil produced $207.6 \mathrm{mg} \mathrm{CO}_{2}-\mathrm{C} \mathrm{kg}^{-1}$, and consumed $19.14 \%$ 
TABLE 2: $\mathrm{CH}_{4}$ production, $\mathrm{CO}_{2}$ evolution and $\mathrm{O}_{2}$ uptake of soils collected from three slope positions, and incubated for 28 days under flooding (average values \pm standard error, $n=3$ ).

\begin{tabular}{lccccc}
\hline \multirow{2}{*}{ Slope position } & \multirow{2}{*}{ Soil depth $(\mathrm{cm})$} & \multicolumn{2}{c}{$\mathrm{CH}_{4}$ production } & \multirow{2}{*}{$\mathrm{CO}_{2}$ evolution $\left(\mathrm{mg} \mathrm{C} \mathrm{kg}^{-1}\right)$} & \multirow{2}{*}{$\mathrm{O}_{2}$ uptake \% (v/v) } \\
& & Total $\left(\mathrm{mg} \mathrm{C} \mathrm{kg}^{-1}\right)$ & Rate $\left(\mathrm{mg} \mathrm{C} \mathrm{kg} \mathrm{d}^{-1}\right)$ & $138.1 \pm 2.56$ & $14.61 \pm 0.85$ \\
\multirow{2}{*}{ Top } & $0-20$ & $0.3595 \pm 0.118$ & 0.0316 & $110.2 \pm 2.19$ & $8.73 \pm 0.04$ \\
\hline \multirow{2}{*}{ Middle } & $20-40$ & $0.0017 \pm 0.001$ & 0.0001 & $207.6^{* * *} \pm 2.34$ & $19.14^{* *} \pm 0.10$ \\
& $0-20$ & $3.1679^{* * *} \pm 0.140$ & 0.3042 & $174.6^{* * *} \pm 0.48$ & $18.49^{* * *} \pm 0.29$ \\
\hline \multirow{2}{*}{ Bottom } & $20-40$ & $1.3538^{* * *} \pm 0.129$ & 0.1162 & $106.7^{* *} \pm 0.13$ & $11.65^{* *} \pm 0.12$ \\
& $0-20$ & $0.0584 \mathrm{~ns} \pm 0.011$ & 0.0065 & $47.8^{* * *} \pm 0.59$ & $7.71 \mathrm{~ns} \pm 0.13$ \\
\hline
\end{tabular}

$*, * *, * * *$, different from the Top position (reference soil) at $P<0.05, P<0.01$ and $P<0.001$, respectively, according to Student's $t$-test; ns-not significant difference.

(v/v). At the beginning of $\mathrm{CH}_{4}$ evolution in this soil after 17 days of incubation, there was only 3.21\% (v/v) $\mathrm{O}_{2}$ left in the headspace. At the end of incubation, $\mathrm{O}_{2}$ was hardly depleted (1.36\% v/v in the headspace). The Top and Bottom soils consumed 14.6 and $11.6 \%(\mathrm{v} / \mathrm{v}) \mathrm{O}_{2}$, respectively, which yielded the final $\mathrm{O}_{2}$ concentration in the headspace of 5.88 and $8.85 \%(\mathrm{v} / \mathrm{v})$, respectively.

The subsurface-flooded soils showed some lower respiration (Figures 1(e) and 1(f)). An exception was the Middle soil, which produced as much as $174.6 \mathrm{mg} \mathrm{CO}_{2}-\mathrm{C} \mathrm{kg}^{-1}$, while it consumed $18.5 \%(\mathrm{v} / \mathrm{v}) \mathrm{O}_{2}\left(2 \% \mathrm{v} / \mathrm{v} \mathrm{O}_{2}\right.$ left in the headspace). The other soils followed the tendency observed in $\mathrm{CH}_{4}$ production; thus they evolved less $\mathrm{CO}_{2}$ and consumed less $\mathrm{O}_{2}\left(<111 \mathrm{mg} \mathrm{CO} 2-\mathrm{C} \mathrm{kg}^{-1}\right.$ and $<8.8 \%$ (v/v), resp.). In most cases, the $\mathrm{CO}_{2}$ produced and $\mathrm{O}_{2}$ consumed in the course of methanogenic incubation in the Middle and Bottom soils significantly differed from those in Top soil (Table 2).

\subsection{Methanotrophic Activity of Soils from Different Slope Posi-} tions. The capacity of $\mathrm{CH}_{4}$ consumption in the upper soils was slightly modified by the slope position (Figure 2(a)). All the soils collected at the $0-20 \mathrm{~cm}$ depth consumed completely the added methane (100\%) after a 3-4 day lag. The highest methanotrophic activity was observed in the Middle soil, which rapidly utilized the whole gas between 4 and 9 day, at a rate of $-20.66 \mathrm{mg} \mathrm{CH}_{4}-\mathrm{C} \mathrm{kg}^{-1} \mathrm{~d}^{-1}$ (Table 3). $\mathrm{CH}_{4}$ consumption in the Top and Bottom samples lasted some longer, until the 11 th incubation day $(16.08$ and $17.58 \mathrm{mg}$ $\mathrm{CH}_{4}-\mathrm{C} \mathrm{kg}^{-1} \mathrm{~d}^{-1}$, resp.).

Deeper soil layers showed greater variation in $\mathrm{CH}_{4}$ oxidation capacity (Figure $2(\mathrm{~d})$ ). The highest activity was shown, again, by the soil collected from Middle position, which completely utilized $121.3 \mathrm{mg} \mathrm{CH}_{4}-\mathrm{C} \mathrm{kg}^{-1}$ between the 3rd and 9th incubation days (at a rate of $-12.26 \mathrm{mg} \mathrm{CH}_{4}$ $\left.\mathrm{C} \mathrm{kg}^{-1} \mathrm{~d}^{-1}\right)$. The Bottom soil consumed $116.49 \mathrm{mg} \mathrm{CH}_{4}{ }^{-}$ $\mathrm{C} \mathrm{kg}^{-1}$ (92\% of initial) at a rate of $-7.95 \mathrm{mg} \mathrm{CH}_{4}-\mathrm{C} \mathrm{kg}^{-1} \mathrm{~d}^{-1}$, whereas the Top soil oxidized only $14 \%$ of added $\mathrm{CH}_{4}$, at a low rate of $-0.799 \mathrm{mg} \mathrm{CH}_{4}-\mathrm{C} \mathrm{kg}^{-1} \mathrm{~d}^{-1}(P<0.001)$ (Table 3$)$.

In general, $\mathrm{CO}_{2}$ production and $\mathrm{O}_{2}$ consumption followed the tendencies in $\mathrm{CH}_{4}$ uptake (Figure 2). The Middle soil of both depths showed an apparent increase in $\mathrm{CO}_{2}$, and a decrease in $\mathrm{O}_{2}$ in the headspace after 4 days of incubation, when $\mathrm{CH}_{4}$ oxidation started. Total $\mathrm{CO}_{2}$ evolution of $198.9 \mathrm{mg} \mathrm{C} \mathrm{kg}^{-1}$ was, however, similar to that measured in the Top upper soil, which consumed significantly less $\mathrm{CH}_{4}$ (Table 3). The amount of $\mathrm{CO}_{2}$ evolved by the Middle upper soil was significantly higher than that produced in the Bottom soil ( $151.9 \mathrm{mg} \mathrm{C} \mathrm{kg}^{-1}, P<0.001$ ). Among the soils collected from deeper layers, the Middle soil produced more $\mathrm{CO}_{2}$ and consumed more $\mathrm{O}_{2}$ than the other soils, with accumulation of $224.1 \mathrm{mg} \mathrm{CO}_{2}-\mathrm{C} \mathrm{kg}^{-1}$ and utilization of $13.6 \%$ (v/v) $\mathrm{O}_{2}, P<0.001$ (Figure 2).

3.3. Relations between Measured Soil Properties. The amount of methane produced in flooded soils showed a close relationship with the amount of organic $\mathrm{C}$ modified by the soil position in the slope (Figure 3(a)).

Similar significant relations were observed for $\mathrm{CO}_{2}$ produced and $\mathrm{O}_{2}$ consumed during incubation of flooded and wet soils (i.e., in the course of methane production and oxidation, resp.) versus $\mathrm{C}_{\text {org }}$ (Figures 3(a) and 3(b)). Such correlations for methane oxidation were not shown.

\section{Discussion}

Position in the landscape affects the accumulation and redistribution of water, nutrients, sediments, and organic matter. Soils on ridges and upper slopes will tend to loose soil and organic matter that will tend to accumulate on lower slopes and in depressions. Generally, soils in lower-slope positions will tend to have a wetter moisture regime for a longer period [33], while soil $\mathrm{O}_{2}$ concentrations may decrease significantly from ridges to valleys [34]. Methane emission from low-slope positions may be observed already one or three days after summer rainfall, depending on the intensity of precipitation [13]. It has been assumed that, in well-aerated soils, $\mathrm{CH}_{4}$ production in anaerobic microsites could be an important source of methane for methane oxidizing bacteria [35]. Little is known, however, about methane emission when usually well-drained soils become flooded for a short period [13]. The characteristics of $\mathrm{CH}_{4}$ oxidizing and producing communities and the factors which affect these characteristics as well as $\mathrm{CH}_{4}$ transport determine the magnitude of the surface $\mathrm{CH}_{4}$ flux to the atmosphere [36]. Our studies with loess soil collected from different slope positions and incubated under laboratory conditions showed that the slope position significantly affected the soil 
TABLE 3: $\mathrm{CH}_{4}$ consumption, $\mathrm{CO}_{2}$ evolution, and $\mathrm{O}_{2}$ uptake in soils collected from three slope positions and incubated with $5 \mathrm{kPa}$ methane for 21 days (average values \pm standard error, $n=3$ ).

\begin{tabular}{|c|c|c|c|c|c|c|}
\hline \multirow[b]{2}{*}{ Slope position } & \multirow[b]{2}{*}{ Soil depth $(\mathrm{cm})$} & \multicolumn{3}{|c|}{$\mathrm{CH}_{4}$ consumption } & \multirow{2}{*}{$\begin{array}{l}\mathrm{CO}_{2} \text { evolution } \\
\left(\mathrm{mg} \mathrm{C} \mathrm{kg}^{-1}\right)\end{array}$} & \multirow[b]{2}{*}{$\mathrm{O}_{2}$ uptake $\%(\mathrm{v} / \mathrm{v})$} \\
\hline & & Total $\left(\mathrm{mg} \mathrm{C} \mathrm{kg}^{-1}\right)$ & $\%$ of initial $\mathrm{CH}_{4}$ & $\begin{array}{c}\text { Rate } \\
\left(\mathrm{mgCkg}^{-1} \mathrm{~d}^{-1}\right)\end{array}$ & & \\
\hline \multirow{2}{*}{ Top } & $0-20$ & $130.84 \pm 2.31$ & 100 & -16.08 & $186.7 \pm 11.4$ & $11.14 \pm 0.53$ \\
\hline & $20-40$ & $17.80 \pm 2.62$ & 14 & -0.799 & $83.9 \pm 2.86$ & $2.55 \pm 0.11$ \\
\hline \multirow{2}{*}{ Middle } & $0-20$ & $121.36^{*} \pm 0.01$ & 100 & -20.66 & $198.9 \mathrm{~ns} \pm 3.57$ & $11.77 \mathrm{~ns} \pm 0.34$ \\
\hline & $20-40$ & $131.71^{*} \pm 0.80$ & 100 & -12.26 & $224.1^{* * *} \pm 5.26$ & $13.63^{* * *} \pm 0.32$ \\
\hline \multirow{2}{*}{ Bottom } & $0-20$ & $130.96 \mathrm{~ns} \pm 43.7$ & 100 & -17.58 & $151.9 \mathrm{~ns} \pm 5.34$ & $9.44 \mathrm{~ns} \pm 0.38$ \\
\hline & $20-40$ & $116.49^{* * *} \pm 12.2$ & 92 & -7.954 & $104.1^{* *} \pm 3.14$ & $6.99 * * * \pm 0.50$ \\
\hline
\end{tabular}

$*, * *, * * *$, different from the Top (reference) soil at $P<0.05, P<0.01$, and $P<0.001$, respectively, according to Student's $t$-test; ns—not significant difference.

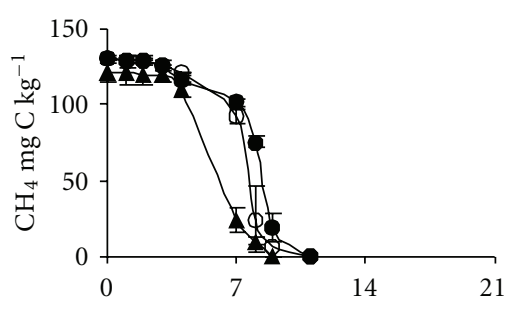

(a)

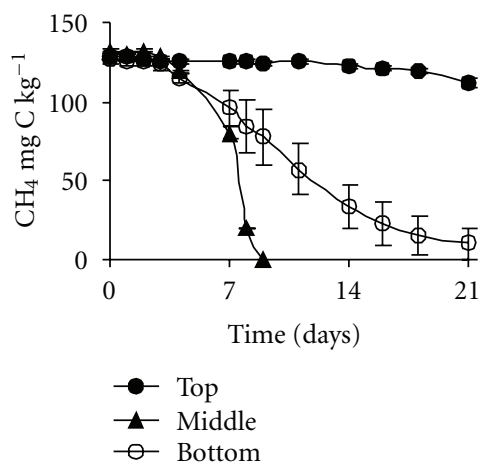

(d)

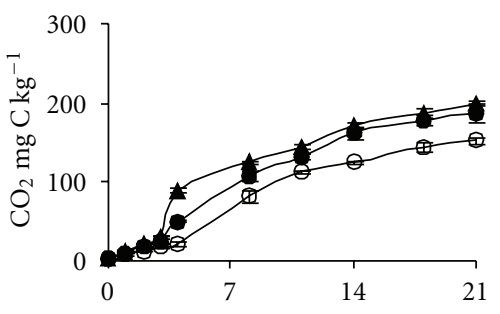

(b)

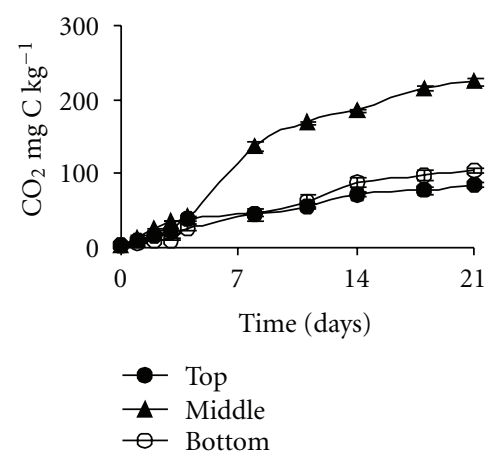

(e)

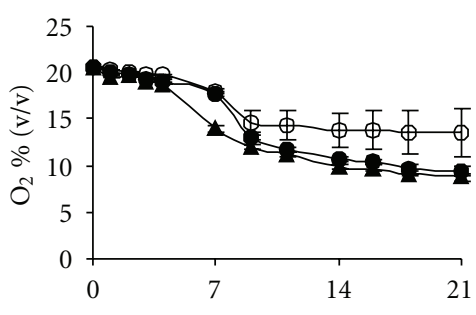

(c)

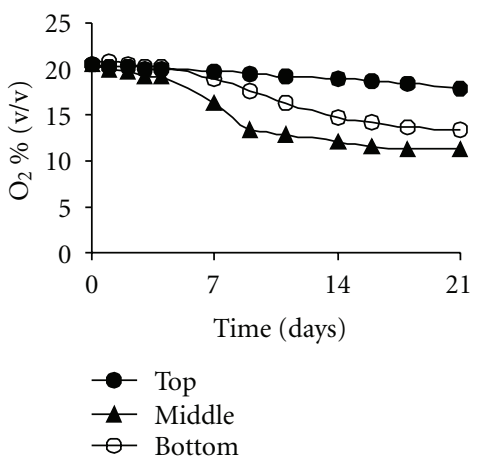

(f)

Figure 2: Changes of $\mathrm{CH}_{4}, \mathrm{CO}_{2}$, and $\mathrm{O}_{2}$ over time in loess soils collected from three slope positions and incubated with added methane, $5 \mathrm{kPa}$ (methanotrophic potential). Top: summit, Middle: back slope, Bottom: bottom of the slope. Upper graphs (a-c) upper soil depth of 0-20 cm; lower graphs (d-f) lower soil depth of 20-40 cm. (a) and (d) cumulative $\mathrm{CH}_{4}$ production; (b) and (e) cumulative $\mathrm{CO}_{2}$ production; (c) and (f) — changes in $\mathrm{O}_{2}$ in the headspace. Points represent triplicate-means with standard error.

potential for $\mathrm{CH}_{4}$ production and oxidation and modified soil respiration involved in $\mathrm{CH}_{4}$ transformations.

We compared soils from the Middle and Bottom positions with the soils at the summit (Top) position, which may be regarded as a reference soil. The methane production potential of the soil from the Middle position significantly increased (9-fold in the upper soil layer and even more in the deeper layer $P<0.001$ ), while at the Bottom position $\mathrm{CH}_{4}$ production did not changed significantly (Table 2 ). In turn, the methane oxidation potential was unchanged in the 0 $20 \mathrm{~cm}$ layer (as all upper soils depleted all added $\mathrm{CH}_{4}$ ) but strongly increased in the $20-40 \mathrm{~cm}$ soil layers and form the level of $14 \%$ in the Top soil, to $92-100 \%$ in the other soils $(P<0.05$ or $P<0.001)$.
In the course of methanogenesis, soil respiration underwent modification similar to that observed for the methanogenic potential. In the Middle slope position, $\mathrm{CO}_{2}$ production and $\mathrm{O}_{2}$ uptake were significantly stimulated as compared with the Top soil (by 50\% and 30\%, resp., $P<0.001$ and $P<0.01$ ). Soil collected at the Bottom position showed lower respiration than the Top soil (both $\mathrm{CO}_{2}$ and $\mathrm{O}_{2}$ less by about $20 \%, P<0.01)$. In the deeper soil layer, the changes were generally more pronounced.

Changes in soil respiration in the course of methanotrophy were apparently dependent on soil depth. In comparison with the Top site, the upper Middle and Bottom soils were not changed, as all soils consumed comparable amounts of methane. However, soils sampled from a depth of $20-40 \mathrm{~cm}$ 


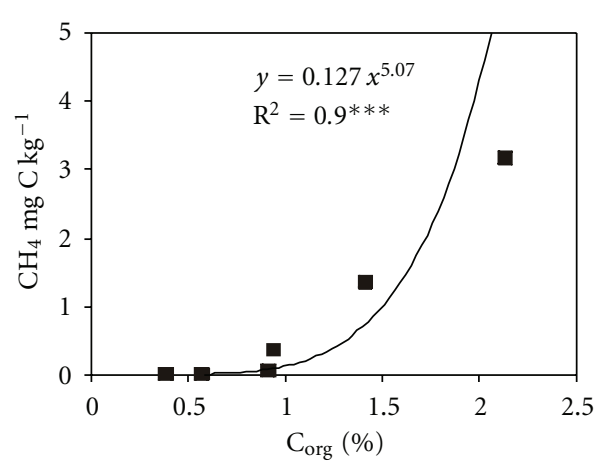

(a)

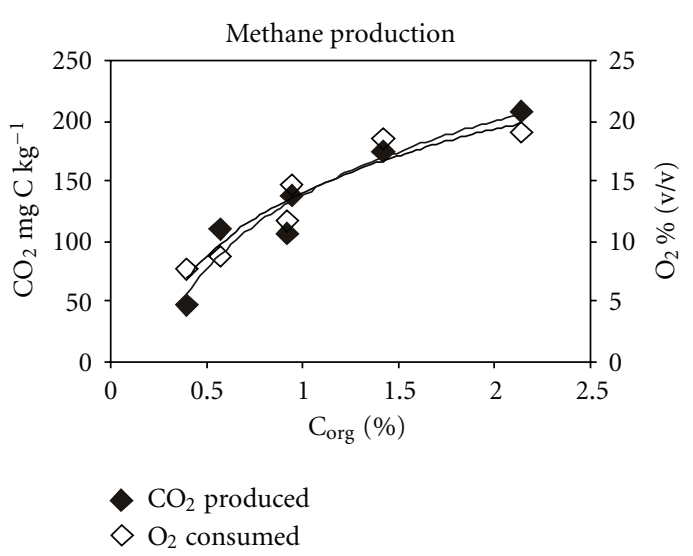

(b)

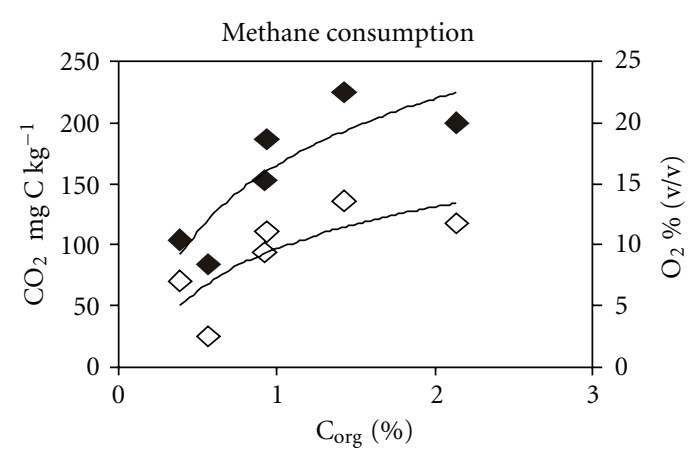

$\mathrm{CO}_{2}$ produced

$\diamond \mathrm{O}_{2}$ consumed

(c)

FIgURe 3: Relationships between total gases produced or consumed over time and organic carbon $\left(\mathrm{C}_{\text {org }}\right)$ in soils collected from different slope positions. (a) $\mathrm{CH}_{4}$ produced in flooded soils versus $\mathrm{C}_{\mathrm{org}}$; (b) $\mathrm{CO}_{2}$ produced and $\mathrm{O}_{2}$ consumed in flooded soils versus $\mathrm{C}_{\text {org }}(y=$ $\left.7.60 \cdot \operatorname{Ln}(x)+14.1, R^{2}=0.92^{* * *}\right)$ and $\left(y=88.4 \cdot \operatorname{Ln}(x)+138.7, R^{2}=0.93^{* * *}\right)$; respectively, (c) $\mathrm{CO}_{2}$ produced and $\mathrm{O}_{2}$ consumed in wet soils enriched with $\mathrm{CH}_{4}$ soils versus $\mathrm{C}_{\text {org }}\left(y=78.1 \cdot \operatorname{Ln}(x)+165.2, R^{2}=0.74^{* * *}\right)$ and $\left(y=4.38 \cdot \operatorname{Ln}(x)+4.60, R^{2}=0.92^{*}\right)$, respectively. Points present mean values. ${ }^{* * *}$ and $*, P<0.001$ and $P<0.05$, respectively.

respired at a significantly higher rate than the Top soil (up to 5 times $)(P<0.001)$.

In the experiments of [21], water-stable aggregates were significantly different among landscape positions and decreased from lower $>$ middle $>$ summit landscape position. However, in some soils, the landscape effect was insignificant, for example, for enzyme activities or emission of $\mathrm{CH}_{4}$ and $\mathrm{CO}_{2}[19,21]$. Fang et al. [17] observed that neither potential net $\mathrm{N}$ mineralization nor nitrification was differentiated by the slope position, nor was accumulative emissions of $\mathrm{N}_{2} \mathrm{O}$ or $\mathrm{CO}_{2}$ from incubated soils in laboratory; in contrast, the ability to oxide $\mathrm{CH}_{4}$ appeared to decrease from the bottom to the top.

It is well known that methane fluxes are strongly regulated by the presence or absence of methanotrophs $\left(\mathrm{CH}_{4}\right.$ oxidizers), which are generally found in the upper (0$20 \mathrm{~cm})$ soil [37]. On the other hand, methanogens $\left(\mathrm{CH}_{4}\right.$ producers) use labile carbon compounds that were produced in the root zone and are less abundant with increasing distance from the soil surface, and rates of potential $\mathrm{CH}_{4}$ production decline with depth below the aerobic zone [38]. However, deeper soil also contributes to $\mathrm{CH}_{4}$ emission. In our experiment, both upper $(0-20 \mathrm{~cm})$ and lower $(20-40 \mathrm{~cm})$ soil layers of the Middle position evolved $\mathrm{CH}_{4}$. The process started relatively fast, after 17 days of flooded incubation at $25^{\circ} \mathrm{C}$, and $\mathrm{CH}_{4}$ reached $3.16 \mathrm{mg} \mathrm{CH}_{4}-\mathrm{C} \mathrm{kg}^{-1}(0.35 \% \mathrm{v} / \mathrm{v}$ of $\mathrm{CH}_{4}$ in the headspace) over 28-day incubation. Similarly, Mayer and Conrad [39] observed a rapid increase in $\mathrm{CH}_{4}$ production within 25 days of flooding an upland agricultural soil and a forest soil. It is possible that, in our experiment, $\mathrm{CH}_{4}$ emissions did not occur in the other soils since $\mathrm{O}_{2}$, which is the most thermodynamically favourable electron acceptor [29,37], was still in the headspace. Methanogenesis is evidently inhibited by $\mathrm{O}_{2}$ this is apparent from field studies that show no overlap in the depth distributions of $\mathrm{O}_{2}$ penetration in soils or sediments and net $\mathrm{CH}_{4}$ production [38]. However, the lack of $\mathrm{CH}_{4}$ production in the presence of $\mathrm{O}_{2}$ in situ may be due to a combination of factors, of which $\mathrm{O}_{2}$ toxicity is just one. For example, methanogens are more sensitive to desiccation than $\mathrm{O}_{2}$ exposure in a paddy 
soil [40]. In our experiment, methane formation in the Middle soil was preceded by relatively rapid $\mathrm{O}_{2}$ consumption, which created soil hypoxia and allowed methanogens to develop. However, $\mathrm{CH}_{4}$ was also detected in the upper Top soil on day $21(0.008 \% \mathrm{v} / \mathrm{v}$ in the headspace), although there was $8.4 \%(\mathrm{v} / \mathrm{v}) \mathrm{O}_{2}$ in the headspace.

Probably, the mechanisms of the slope position effect on methanogenic and methanotrophic activities are complex. Some decline in soil $\mathrm{pH}$ was observed for the Middle and Bottom soils as compared with the Top soil (from $\mathrm{pH} 8.1$ to 7.6-7.9, Table 1). However, most methanogenic communities seem to be dominated by neutrophilic species [38]; in a survey of 68 methanogenic species conducted by Garcia et al. [41], most species grew best in a $\mathrm{pH}$ range from 6 to 8 . Evidently, in our experiment, the soil position changed the sand, silt, and clay content at the depth of $20-40 \mathrm{~cm}$ (Table 1). The clay fraction content decreased from $6.3 \%$ in the Top soil to 4.2 and $4.3 \%$ in the Middle and Bottom soils, respectively. Similarly, the silt content decreased from $77.4 \%$ to 68.7 and $61.6 \%$, respectively. A change in the sand content (an increase from $16.3 \%$ in the Top position to 27.5 and $34.5 \%$ in the Middle and Bottom positions, resp.) probably stimulated $\mathrm{CH}_{4}$ oxidation due to better draining and easier gas diffusion in soil containing more sand, because $\mathrm{O}_{2}$ is necessary for monooxygenase enzyme which catalyzes methane oxidation [42]. Coarse-textured soils have been documented as supporting $\mathrm{CH}_{4}$ oxidation by enhancing gas diffusion $\left(\mathrm{CH}_{4}\right.$ and $\left.\mathrm{O}_{2}\right)$ into the soil [43].

Paluszek and Żembrowski [44] present their findings from a long-term study designed to explore effect of accelerated erosion on soil properties in a loessial landscape. They observed that slight, moderate, and severe erosion has an adverse effect on soil physical properties. The clay content and bulk density in Ap horizons of eroded soils are on the increase whereas the content of organic matter, content of water-stable aggregates, field water capacity, and retention of water useful for plants decrease. In the consequence, soil porosity, air capacity, and air permeability deteriorate. By contrast, in very severely eroded soils whose Ap horizons developed from carbonate loess, pore-size distribution, field water capacity and retention of water useful for plants are favourable and comparable to those in noneroded soils [44].

High organic $\mathrm{C}$ content in the Middle soil, as compared with the Top soil (Table 1), stimulated methane production under soil hypoxia. Probably, small differences in $\mathrm{C}_{\mathrm{org}}$ between Top and Bottom soils may explain insignificant differences in methanogenic activity. Nevertheless, high correlation coefficients obtained for relationships between $\mathrm{C}_{\text {org }}$ and produced $\mathrm{CH}_{4}$, evolved $\mathrm{CO}_{2}$, and consumed $\mathrm{O}_{2}$ confirm their universal character (Figure 3). However, better explanation of the changes observed in our experiment needs more information on the properties of tested soils at different slope positions.

\section{Acknowledgment}

The paper was partly financed by the State Committee for Scientific Research, Poland (Grants no. N N310 043838). The authors greatly appreciate Professor R. Dębicki (Maria CurieSkłodowska University in Lublin, Poland) who inspired us to perform these studies.

\section{References}

[1] K. Knittel and A. Boetius, "Anaerobic oxidation of methane: progress with an unknown process," Annual Review of Microbiology, vol. 63, pp. 311-334, 2009.

[2] Q. Zhuang, J. M. Melack, S. Zimov, K. M. Walter, C. L. Butenhoff, and M. Aslam K Khalil, "Global methane emissions from wetlands, rice paddies, and lakes," Eos, vol. 90, no. 5, pp. 37-38, 2009.

[3] M. J. Prather and J. Hsu, "Coupling of nitrous oxide and methane by global atmospheric chemistry," Science, vol. 330, no. 6006, pp. 952-954, 2010.

[4] D. Fowler, K. Pilegaard, M. A. Sutton et al., "Atmospheric composition change: ecosystems-atmosphere interactions," Atmospheric Environment, vol. 43, no. 33, pp. 5193-5267, 2009.

[5] Intergovernmental Panel on Climate Change, "Climate change 2007: the scientific basis," Contribution of Working Group 1 to the Fourth Assessment Report of the Intergovernmental Panel on Climate Change, Cambridge University Press, Cambridge, UK, 2007.

[6] E. Topp and E. Pattey, "Soils as sources and sinks for atmospheric methane," Canadian Journal of Soil Science, vol. 77, no. 2, pp. 167-178, 1997.

[7] A. S. K. Chan and T. B. Parkin, "Effect of land use on methane flux from soil," Journal of Environmental Quality, vol. 30, no. 3, pp. 786-797, 2001.

[8] C. Brink, E. van Ierland, L. Hordijk, and C. Kroeze, "Costeffective emission abatement in europe considering interrelations in agriculture," TheScientificWorldJournal, vol. 1, pp. 814-821, 2001.

[9] W. Stępniewski, "Aeration of soils and plants," in Encyclopedia of Agrophysics, J. Gliński, J. Horabik, and J. Lipiec, Eds., pp. 8-12, Springer Science+Business Media B.V., Dordrecht, The Netherlands, 1st edition, 2011.

[10] W. Stępniewski, Z. Stępniewska, R. P. Bennicelli, and J. Gliński, Oxygenology in Outline, Institute of Agrophysics of the Polish Academy of Sciences, Lublin, Poland, 2005.

[11] M. Brzezińska, Z. Stępniewska, and W. Stępniewski, "Soil oxygen status and dehydrogenase activity," Soil Biology and Biochemistry, vol. 30, no. 13, pp. 1783-1790, 1998.

[12] A. S. K. Chan and T. B. Parkin, "Methane oxidation and production activity in soils from natural and agricultural ecosystems," Journal of Environmental Quality, vol. 30, no. 6, pp. 1896-1903, 2001.

[13] F. L. Wang and J. R. Bettany, "Methane emission from Canadian prairie and forest soils under short term flooding conditions," Nutrient Cycling in Agroecosystems, vol. 49, no. 13, pp. 197-202, 1997.

[14] M. Brzezińska, "Impact of treated wastewater on biological activity and accompanying processes in organic soils (field and model experiments)," Acta Agrophysica, vol. 131, pp. 7-164, 2006 (Polish).

[15] S. Abrishamkesh, M. Gorji, and H. Asadi, "Long-term effects of land use on soil aggregate stability," International Agrophysics, vol. 25, no. 2, pp. 103-108, 2011.

[16] A. Akbarzadeh, R. T. Mehrjardi, H. G. Refahi, H. Rouhipour, and M. Gorji, "Using soil binders to control runoff and soil loss in steep slopes under simulated rainfall," International Agrophysics, vol. 23, no. 2, pp. 99-109, 2009. 
[17] Y. Fang, P. Gundersen, W. Zhang et al., "Soil-atmosphere exchange of $\mathrm{N} 2 \mathrm{O}, \mathrm{CO} 2$ and $\mathrm{CH} 4$ along a slope of an evergreen broad-leaved forest in southern China," Plant and Soil, vol. 319, no. 1-2, pp. 37-48, 2009.

[18] A. Ferrero and J. Lipiec, "Determining the effect of trampling on soils in hillslope-woodlands," International Agrophysics, vol. 14, no. 1, pp. 9-16, 2000.

[19] C. N. Gacengo, C. W. Wood, J. N. Shaw, R. L. Raper, and K. S. Balkcom, "Agroecosystem management effects on greenhouse gas emissions across a coastal plain catena," Soil Science, vol. 174, no. 4, pp. 229-237, 2009.

[20] M. T. Rashid and R. P. Voroney, "Field-scale application of oily food waste and nitrogen fertilizer requirements of corn at different landscape positions," Journal of Environmental Quality, vol. 34, no. 3, pp. 963-969, 2005.

[21] R. P. Udawatta, R. J. Kremer, B. W. Adamson, and S. H. Anderson, "Variations in soil aggregate stability and enzyme activities in a temperate agroforestry practice," Applied Soil Ecology, vol. 39, no. 2, pp. 153-160, 2008.

[22] J. Rejman, "Effect of water and tillage erosion on transformation of soils and loess slopes," Acta Agrophysica, vol. 136, pp. 5-91, 2006 (Polish).

[23] R. Turski, J. Paluszek, and A. Slowinska-Jurkiewicz, "The effect of erosion on the spatial differentiation of the physical properties of Orthic Luvisols," International Agrophysics, vol. 6, no. 3-4, pp. 123-136, 1992.

[24] P. Gliński and Z. Stępniewska, "Changes of redox properties in slightly eroded loess soil," Acta Agrophysica, vol. 4, no. 3, pp. 669-686, 2004.

[25] P. Gliński and R. Dębicki, "Degradation of loessial soils in the Ciemięga river basin,” Acta Agrophysica, vol. 23, pp. 39-46, 1999.

[26] M. Brzezińska, P. Rafalski, T. Włodarczyk, P. Szarlip, and K. Brzeziński, "How much oxygen is needed for acetylene to be consumed in soil?" Journal of Soils and Sediments, vol. 11, no. 7, pp. 1142-1154, 2011.

[27] T. Włodarczyk, W. Stępniewski, and M. Brzezińska, "Dehydrogenase activity, redox potential, and emissions of carbon dioxide and nitrous oxide from Cambisols under flooding conditions," Biology and Fertility of Soils, vol. 36, no. 3, pp. 200 206, 2002.

[28] M. Ryzak and A. Bieganowski, "Determination of particle size distrubution of soil using laser diffraction-comparison with areometric method," International Agrophysics, vol. 24, no. 2, pp. 177-181, 2010.

[29] J. Gliński and W. Stẹpniewski, Soil Aeration and Its Role for Plants, CRC Press, Boca Raton, Fla, USA, 1985.

[30] T. E. Freitag and J. I. Prosser, "Correlation of methane production and functional gene transcriptional activity in a peat soil," Applied and Environmental Microbiology, vol. 75, no. 21, pp. 6679-6687, 2009.

[31] X. Xu and K. Inubushi, "Temperature effects on ethylene and methane production from temperate forest soils," Chinese Science Bulletin, vol. 54, no. 8, pp. 1426-1433, 2009.

[32] J. Gulledge and J. P. Schimel, "Moisture control over atmospheric $\mathrm{CH} 4$ consumption and $\mathrm{CO} 2$ production in diverse Alaskan soils," Soil Biology and Biochemistry, vol. 30, no. 8-9, pp. 1127-1132, 1998.

[33] B. Murphy, B. Wilson, and A. Rawson, "Development of a soil carbon benchmark matrix for central west NSW," in Proceedings of the 19th World Congress of Soil Science. Soil Solutions for a Changing World, Brisbane, Australia, August 2010.

[34] W. L. Silver, A. E. Lugo, and M. Keller, "Soil oxygen availability and biogeochemistry along rainfall and topographic gradients in upland wet tropical forest soils," Biogeochemistry, vol. 44, no. 3, pp. 301-328, 1999.

[35] R. Conrad, "Soil microbial processes and the cycling of atmospheric trace gases," Advances in Microbial Ecology, vol. 14, pp. 207-250, 1995.

[36] M. A. Bradford, P. Ineson, P. A. Wookey, and H. M. LappinScott, "Role of $\mathrm{CH} 4$ oxidation, production and transport in forest soil CH4 flux," Soil Biology and Biochemistry, vol. 33, no. $12-13$, pp. 1625-1631, 2001.

[37] A. Matson, D. Pennock, and A. Bedard-Haughn, "Methane and nitrous oxide emissions from mature forest stands in the boreal forest, Saskatchewan, Canada," Forest Ecology and Management, vol. 258, no. 7, pp. 1073-1083, 2009.

[38] J. P. Megonigal, M. E. Hines, and P. T. Visscher, "Anaerobic metabolism: linkages to trace gases and aerobic processes," in Biogeochemistry, W. H. Schlesinger, Ed., pp. 317-424, ElsevierPergamon, Oxford, UK, 2004.

[39] H. P. Mayer and R. Conrad, "Factors influencing the population of methanogenic bacteria and the initiation of methane production upon flooding of paddy soil," FEMS Microbiology Ecology, vol. 73, no. 2, pp. 103-111, 1990.

[40] S. Fetzer, F. Bak, and R. Conrad, "Sensitivity of methanogenic bacteria from paddy soil to oxygen and desiccation," FEMS Microbiology Ecology, vol. 12, no. 2, pp. 107-115, 1993.

[41] J.-L. Garcia, B. K. C. Patel, and B. Ollivier, "Taxonomic, phylogenetic, and ecological diversity of methanogenic Archaea," Anaerobe, vol. 6, no. 4, pp. 205-226, 2000.

[42] X. K. Xu and K. Inubushi, "Ethylene oxidation, atmospheric methane consumption, and ammonium oxidation in temperate volcanic forest soils," Biology and Fertility of Soils, vol. 45, no. 3, pp. 265-271, 2009.

[43] A. Saari, P. J. Martikainen, A. Ferm et al., "Methane oxidation in soil profiles of Dutch and Finnish coniferous forests with different soil texture and atmospheric nitrogen deposition," Soil Biology and Biochemistry, vol. 29, no. 11-12, pp. 16251632, 1997.

[44] J. Paluszek and W. Żembrowski, "Improvement of the soils exposed to erosion in a loessial landscape," Acta Agrophysica, vol. 164, pp. 5-159, 2008 (Polish). 

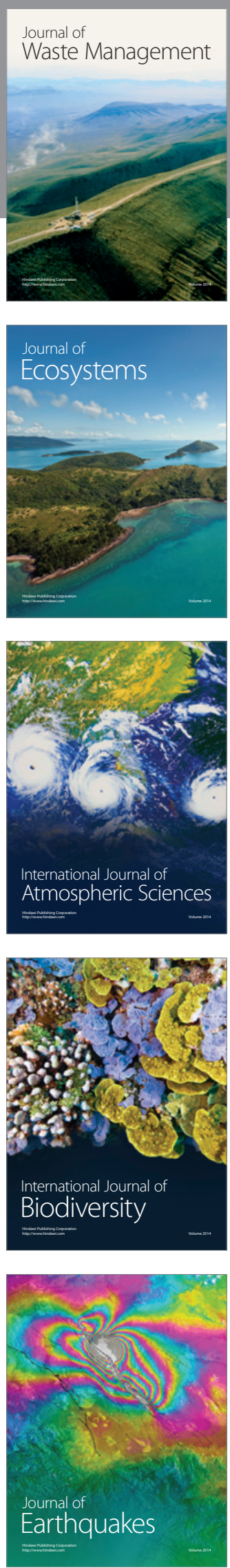
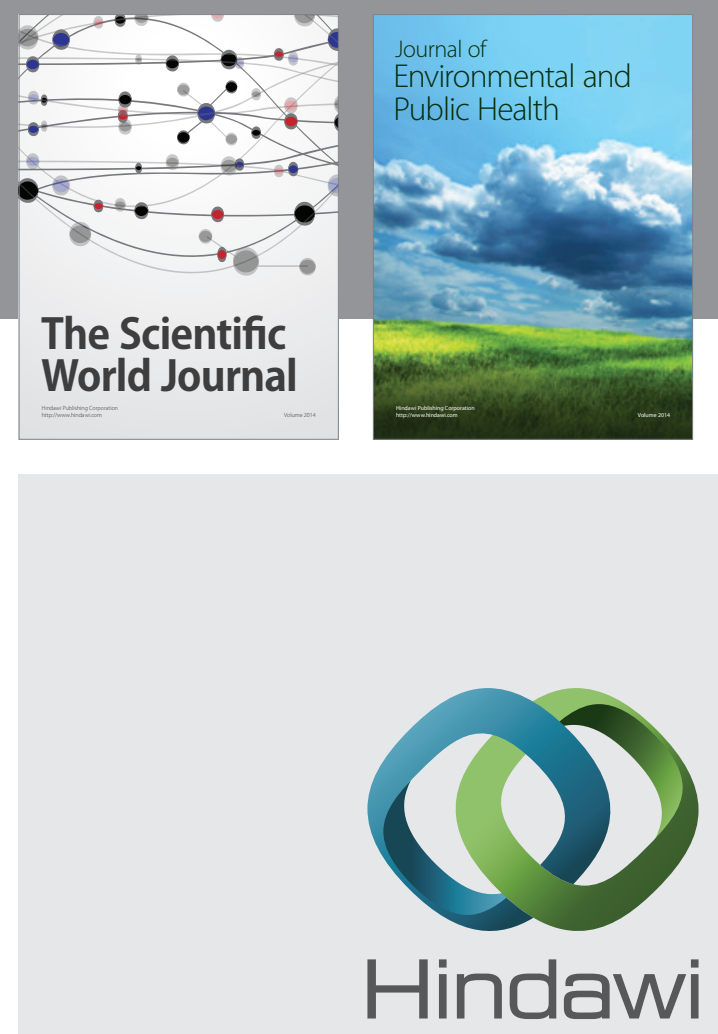

Submit your manuscripts at

http://www.hindawi.com
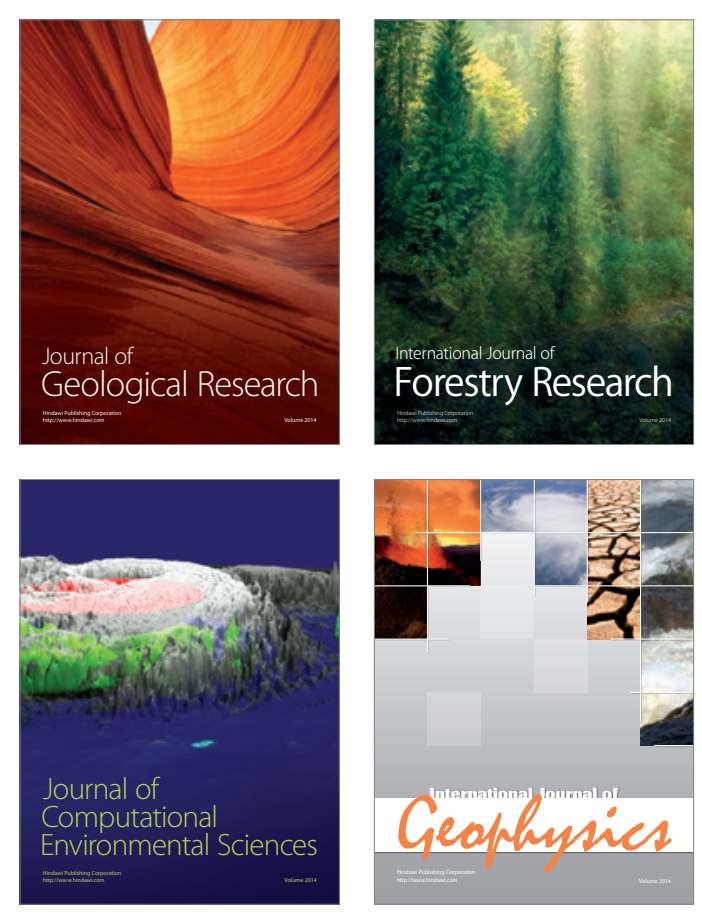
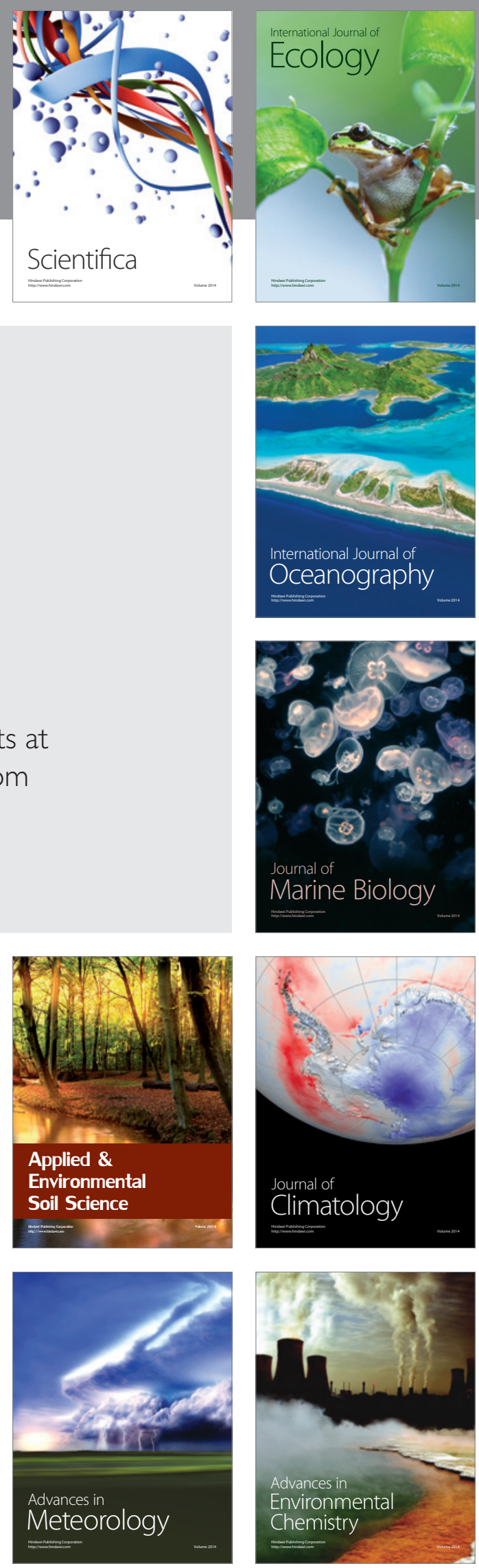